\title{
WATERTIGHT COMPARTMENTS: GetTing BACK TO THE CONSTITUTiOnAL Division OF POWERS
}

\begin{abstract}
ASHER HONICKMAN ${ }^{*}$
This article offers a fresh examination of the constitutional division of powers. The author argues that sections 91 and 92 of the Constitution Act, 1867 establish exclusive jurisdictional spheres - what the Privy Council once termed "watertight compartments." This mutual exclusivity is emphasized and reinforced throughout these sections and leaves very little room for legitimate overlap. While some degree of overlap is permissible under this scheme - particularly incidental effects, genuine double aspects, and limited ancillary powers - overlap must be constrained in a principled fashion to comply with the exclusivity principle. The modern trend toward flexibility and freer overlap is contrary to the constitutional text. The author argues that while some deviation from the text is inevitable due to the presumption of constitutionality and stare decisis, the Supreme Court should return to a more exclusivist footing in accordance with the text.
\end{abstract}

\section{TABLE OF CONTENTS}

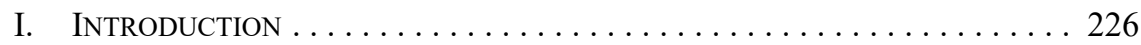

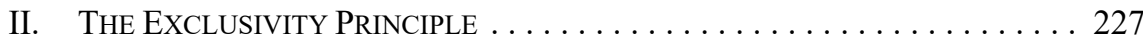

A. From Quebec to the British Parliament $\ldots \ldots \ldots \ldots \ldots 227$

B. The Non Obstante Clause and the Deeming Provision ..... 231

C. CONCURRENT Powers . . ....................... 234

III. Pith And Substance And Legitimate OverlaP $\ldots \ldots \ldots \ldots \ldots \ldots 235$

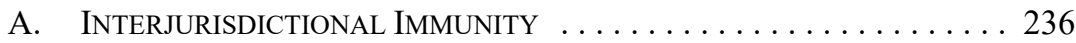

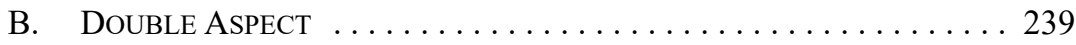

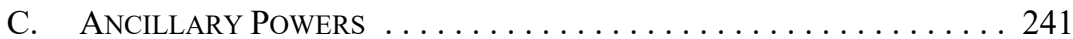

IV. Getting Back to the Words $\ldots \ldots \ldots \ldots \ldots \ldots \ldots \ldots \ldots \ldots \ldots \ldots \ldots \ldots$

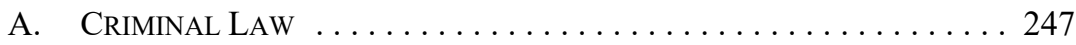

B. Peace, Order, AND Good Government . . . . . . . . . . . 248

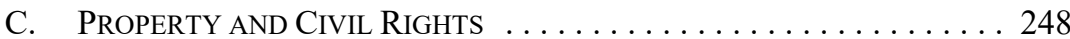

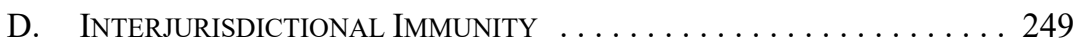

E. ANCILlary POWERS . . . . . . . . . . . . . . . . . . . . . . . 249

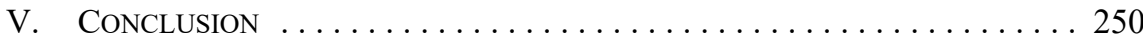

Partner, Matthews Abogado LLP, Toronto, Ontario. He is the founder and chair of Advocates for the Rule of Law. The author would like to thank Mark Mancini, Gerard Kennedy, John Sikkema, and Leonid Sirota for their helpful edits and comments. 
Useful as decided cases are, it is always advisable to get back to the words of the

[BNA] Act itself and to remember the object with which it was passed. ${ }^{1}$

\section{INTRODUCTION}

Judge-made doctrine increasingly dominates the constitutional division of powers in Canada. We read about the Supreme Court's preference for a "cooperative, flexible federalism" 2 based on the doctrines of double aspect and ancillary powers. This "approach to federalism," "which allows for "a fair amount of interplay and indeed overlap between federal and provincial powers," is described as the "dominant tide," and is contrasted with the "undertow" of a more "rigid" federalism that favours the doctrine of interjurisdictional immunity. ${ }^{5}$ It is as if the Constitution creates a very basic blueprint and leaves the "heavy lifting" to judges, whose task it is to guide the course of Canadian federalism along a pragmatic path. Of course, we know this is not so. The Constitution is not "an empty vessel to be filled with whatever meaning we might wish from time to time." ${ }^{\prime 6}$ The Constitution Act, $1867,{ }^{7}$ in particular, is a technical legal document and it establishes a very particular model of federalism. It is that particular model which I expound in this article. Briefly, I intend to demonstrate that the Constitution Act, 1867 establishes mutually exclusive jurisdictional spheres of limited power designed to minimize, if not outright prevent, jurisdictional overlap (save and except for expressly concurrent powers). Canada's "original structure" is, to quote Lord Atkin, one of "watertight compartments."

This article is divided into three substantive parts. In Part II, I examine the exclusivity principle, which is stated and reinforced throughout sections 91-95 of the Constitution Act, 1867. In Part III, I discuss the pith and substance doctrine and the way in which that doctrine should be understood and applied in light of the textual imperative that each order may exclusively make laws "in relation to Matters coming within" that order's enumerated powers. Along the same lines, I discuss the ways in which the powers in sections 91 and 92

This quotation comes from the Privy Council's decision, written by Lord Sankey, in Reference re the Regulation and Control of Aeronautics in Canada, [1931] UKPC 93, [1932] AC 54 at 70 [Aeronautics Reference].

3 Reference re Assisted Human Reproduction Act, 2010 SCC 61, [2010] 3 SCR 457 at para 139 [AHRA Reference].

4 OPSEU V Ontario (Attorney General), [1987] 2 SCR 2 at 18 [OPSEU]:

It is true that doctrines like interjurisdictional and Crown immunity and concepts like "watertight compartments" qualify the extent of that interplay. But it must be recognized that these doctrines and concepts have not been the dominant tide of constitutional doctrines; rather they have been an undertow against the strong pull of pith and substance, the aspect doctrine and, in recent years, a very restrained approach to concurrency and paramountcy issues.

See also Canadian Western Bank v Alberta, 2007 SCC 22, [2007] 2 SCR 3 at para 52 [Canadian Western Bank]; Reference Re Securities Act, 2011 SCC 66, [2011] 3 SCR 837 at paras 57-59 [Securities Act Reference].

$5 \quad$ Securities Act Reference, ibid at paras 57-59.

6 Caron v Alberta, 2015 SCC 56, [2015] 3 SCR 511 at para 36 [Caron], citing Reference Re Public Caron v Alberta, 2015 SCC 56, [2015] 3 SCR 511 at para 36 [Car
Service Employee Relations Act (Alta), [1987] 1 SCR 313 at 394.

(UK), 30 \& 31 Vict, c 3, reprinted in RSC 1985, Appendix II, No 5. Its original name was the British North America Act, 1867, or the BNA Act, prior to the 1982 repatriation of the Canadian Constitution. In this article, I often use the term BNA Act when referring to the Act in its 1867 context.

$8 \quad$ Canada (AG) v Ontario (AG), [1937] UKPC 6, [1937] AC 326 at 354 [Weekly Rest Reference]: "While the ship of state now sails on larger ventures and into foreign waters she still retains the watertight compartments which are an essential part of her original structure." 
can legitimately overlap in harmony with the exclusivity principle, namely genuine double aspects, incidental effects, and limited ancillary powers. In Part IV, I discuss the relationship between the text and judicial doctrine, and outline five areas in which a return to the exclusivity principle would produce a more coherent doctrine.

\section{The Exclusivity Principle}

In this part, I discuss the distribution of legislative powers set out in Part VI (section 9195) of the Constitution Act, 1867, with the principal enumerations of federal and provincial power set out in sections 91 and 92, respectively. I argue that these sections establish a division of powers that is based upon the principle of mutual exclusivity. ${ }^{10}$ This principle is emphasized throughout Part VI of the Constitution Act, 1867 in three distinct ways, which I discuss below: first, by the frequent use of the word "exclusive" or "exclusively"; second, by the non obstante clause and the deeming provision that both appear in section 91, which ensure that the enumerated powers in that section are not overtaken by the broad provincial powers over property and civil rights and matters of a merely private or local nature; and, third, by enumerating the concurrent powers over agriculture and immigration in a separate section of Part VI.

\section{A. From Quebec to The British Parliament}

The preamble to section 91 reads as follows:

It shall be lawful for the Queen, by and with the Advice and Consent of the Senate and House of Commons, to make Laws for the Peace, Order, and good Government of Canada, in relation to all Matters not coming within the Classes of Subjects by this Act assigned exclusively to the Legislatures of the Provinces; and for greater Certainty, but not so as to restrict the Generality of the foregoing Terms of this Section, it is hereby declared that (notwithstanding anything in this Act) the exclusive Legislative Authority of the Parliament of Canada extends to all Matters coming within the Classes of Subjects next hereinafter enumerated. ${ }^{11}$

Similarly, the preamble to section 92 reads as follows:

In each Province the Legislature may exclusively make Laws in relation to Matters coming within the Classes of Subjects next hereinafter enumerated. ${ }^{12}$

In section 91 alone, the words "exclusive" or "exclusively" appear four times. ${ }^{13}$ In Part VI as a whole, they appear seven times - eight if we include the heading above section 92, which reads "Exclusive Powers of Provincial Legislatures." 14 Each one of these references reinforces a fundamental tenet of Canadian federalism: that the Canadian Constitution

10 AHF Lefroy, The Law of Legislative Power in Canada (Toronto: Toronto Law Book, 1897) at 347, 35354. See also RCB Risk, A History of Canadian Legal Thought: Collected Essays, ed by G Blaine Baker \& Jim Phillips (Toronto: University of Toronto Press, 2006). Constitution Act, 1867, supra note 7, s 91 [emphasis added].

Ibid, s 92 [emphasis added].

There are two references in the preamble to section 91, one in section 91(29), and one in the concluding paragraph.

The additional references appear in the preambles to sections $92,92 \mathrm{~A}$, and 93. 
establishes separate and limited jurisdictional spheres and grants each order the exclusive authority to make laws within its respective sphere.

The original Quebec Resolutions, which were adopted by the Fathers of Confederation after the Quebec Conference in October 1864, and which formed the basis of the BNA Act (now the Constitution Act, 1867), did not emphasize the mutual exclusivity of each order's jurisdiction to the same extent as the eventual BNA Act. The preamble to Resolution 29 (the precursor to section 91 of the BNA Act) gave Parliament the power to make laws for the "peace, welfare and good Government of the Federated Provinces ... and especially Laws respecting the following subjects." 15 Unlike the eventual section 91, the preamble to Resolution 29 did not explicitly limit Parliament's power to subjects not assigned exclusively to the provinces. Similarly, Resolution 43 (the precursor to section 92) stated that the "Local Legislatures shall have power to make Laws respecting the following subjects," ${ }^{16}$ again without specifying that the power was exclusive, or that it was limited by Parliament's own exclusive powers.

The exclusive nature of the division was only expressly articulated in Resolution 29(37), which gave Parliament a further residual power to make laws "respecting all matters of a general character, not specially and exclusively reserved for the Local Governments and Legislatures." ${ }^{\prime 17}$ The clear implication was that the provincial powers set out in Resolution 43 were exclusive, and this further implied that Parliament's powers listed in Resolution 29 were exclusive as well. Thus, while the intention of the Resolutions was to create separate and exclusive spheres, that intention had to be gathered from reading the Resolutions together. Had the Resolutions been adopted in toto, they would certainly have been liable to be misconstrued by the courts.

The ambiguities in the Quebec Resolutions became apparent during the Confederation Debates in 1865. Most of the legislators, and especially those who had attended the Quebec Conference, understood that power would be divided between Parliament and the provincial legislatures. John A. Macdonald, for example, noted that "all the great questions which affect the general interests of the confederacy as a whole are confided to the federal parliament, while the local interests and local laws of each section are preserved intact and entrusted to the care of the local bodies." " George Brown was even more explicit, declaring that all local matters would be "banished" from Parliament. ${ }^{19}$ This understanding, however, was not shared by every legislator. Louis-Auguste Olivier, a member of the Legislative Council of the Province of Canada, highlighted the ambiguous preamble to Resolution 29 and argued that it provided Parliament with "unlimited" powers. ${ }^{20}$ Other legislators similarly expressed the view that the Quebec scheme actually established a "legislative union" as opposed to a

15 GP Browne, ed, Documents on the Confederation of British North America (Montreal: McGill-Queen's University Press, 2009) at 157-59 [Browne, Documents].

Ibid at $160-61$.

Ibid at 159 .

Janet Ajzenstat et al, eds, Canada's Founding Debates (Toronto: Stoddart, 1999) at 283 [footnote omitted] [Ajzenstat et al, Canada's Founding Debates].

19 Ibid at 288. T.H. Haviland of Prince Edward Island also commented that "the power of the federal government to interfere with the exclusively internal affairs of any of the confederated provinces would be of the most limited and inconsiderable character" (ibid at 325). Ibid at 291 . 
federal union of divided and enumerated powers, ${ }^{21}$ despite assurances from key players such as Macdonald. ${ }^{22}$

Whether to address the concerns raised by some of the colonial legislators, or simply to offer greater clarity, the framers of the BNA Act made sure to emphasize the exclusivity of each order's jurisdiction. The first "rough draft" of the Act, prepared in January 1867 following the London Conference, condensed Parliament's two residual powers under the Quebec Resolutions (and the London Resolutions) into a single power. The new residuary clause read: "And also for the peace, welfare and good government of the Confederation respecting all matters of a general character, not specially and exclusively herein reserved for the Legislatures." ${ }^{23}$ The draft also provided that the provincial legislatures "shall have exclusive power to make laws respecting the following subjects, with the exception of Agriculture and Immigration, in regard to which Parliament shall have concurrent jurisdiction. ${ }^{24}$

Over the course of the subsequent two months, the framers wrestled with various drafts. The original Resolutions were cast in more legalistic terminology and underwent modest alterations. The final draft was prepared on 9 February 1867, but even this draft went through some last minute changes (some of which are discussed below) before being enacted into law. ${ }^{25}$ By the time Queen Victoria granted Royal Assent on 29 March 1867, the federal structure and its exclusive distribution of powers had been made explicit and indisputable.

The preamble to section 91 grants Parliament the authority to pass laws for the "Peace, Order, and good Government" (POGG) of Canada. ${ }^{26}$ However, unlike the Quebec Resolutions which could have been misconstrued as granting Parliament plenary legislative authority, Parliament's POGG power under the Act is restricted to those subjects not "assigned exclusively"27 to the provinces.

The preamble goes on to state that "for greater Certainty, but not so as to restrict the Generality of the foregoing Terms of this Section," Parliament has the exclusive authority to pass laws in respect of the enumerated subjects in section $91 .{ }^{28}$ The inclusion of this phrase

This is not to say that everyone viewed the Quebec Resolutions as a centralizing document. Some were even of the view that the Quebec Resolutions gave the provinces too much power. On 5 December 1864 , Arthur Gordon, Lieutenant-Governor of New Brunswick penned a letter to Edward Cardwell, Britain's Secretary of State of the Colonies, in which he lamented the lack of centrality in the Quebec Resolutions (Browne, Documents, supra note 15 at 171). He noted that, of the 59 laws passed by the New Brunswick legislature during the last session, only five would have been ultra vires under the Quebec scheme. Gordon followed up with a second letter on 30 January 1865 , expressing the view that "nine tenths, at least, of those whose opinion is worth having are opposed to the scheme" noting that while "a few general subjects are relegated to the centre, there is no central control" (ibid at 174 [emphasis in original]).

See e.g. Ajzenstat et al, Canada's Founding Debates, supra note 18 at 266, 275, 316-17, 324.

Browne, Documents, supra note 15 at 239 [emphasis added].

Ibid at 240 [emphasis added].

This is evident from the differences between the last draft and the BNA Act itself: the non obstante clause was added, the deeming provision was changed, and the provincial residuary power over matters of a merely private or local nature was incorporated.

Constitution Act, 1867, supra note 7, s 91.

Ibid.

Ibid. 
has given rise to what historian G.P. Browne called the "Compartment Problem." ${ }^{29}$ Browne was of the view, reflected in many decisions of the Privy Council, that sections 91 and 92 establish three "compartments" — the federal enumerated powers, the provincial enumerated powers, and the POGG power. The federal enumerated powers are paramount, since Parliament is granted the power to legislate in relation to matters coming within section 91's enumerated powers "notwithstanding anything in this Act" (meaning notwithstanding section 92 's enumeration of provincial powers).$^{30}$ The federal powers outrank the provincial powers, but the provincial powers outrank POGG, to which the non obstante clause ("notwithstanding anything in this Act") does not apply. ${ }^{31}$ Browne's text, Judicial Committee, was written largely in response to the 1939 O'Connor Report. ${ }^{32}$ The O'Connor Report is perhaps the most famous exposition of the BNA Act and offers a powerful critique of many decisions of the Privy Council. W.F. O'Connor was of the view that sections 91 and 92 establish only two compartments: federal powers, which include POGG, and provincial powers, with the former outranking the latter. The phrase "for greater Certainty, but not so as to restrict the Generality of the foregoing Terms of this Section" means that the federal enumerated powers are illustrations of POGG, not a distinct class of powers. Therefore, the non obstante clause, which applies in favour of the federally enumerated powers, applies equally to POGG, meaning that POGG is also paramount to provincial powers. ${ }^{33}$

Leaving the non obstante clause aside for the moment (it will be discussed below), O'Connor would appear to be correct regarding the number of compartments. The "for greater Certainty" phrase strongly suggests that the federal enumerated powers are specific illustrations of POGG as opposed to a separate class of power. What O'Connor failed to recognize however is that, being part of the same compartment, the POGG clause must also inform the interpretation of the enumerated powers. POGG might enjoy the same placement as the enumerated powers, but the corollary is that the federal enumerated powers are subject to the same restriction that is placed upon POGG, namely that Parliament can only make laws in relation to matters coming within subjects that are not "assigned exclusively" to the provinces. In other words, the federally enumerated powers are prima facie powers that have not been assigned exclusively to the provinces and therefore cannot be construed so as to infringe on provincial powers. The recognition of two compartments, as opposed to three, does not mean that the provincial legislatures are subservient to Parliament, but rather that

GP Browne, The Judicial Committee and the British North America Act: An Analysis of the Interpretative Scheme for the Distribution of Legislative Powers (Toronto: University of Toronto Press, 1967) at 39-72 [Browne, Judicial Committee].

Constitution Act, 1867, supra note 7, s 91.

Browne, Judicial Committee, supra note 29 at 36-38.

WF O'Connor, Report Pursuant to Resolution of the Senate Relating to the Enactment of the British North America Act, 1867 (Ottawa: Queen's Printer, 1939) [O’Connor Report].

Browne, Judicial Committee, supra note 29 at 37-40. 
each was, in the words of 19th century legal scholar A.H.F. Lefroy, "supreme in its own domain." ${ }^{34}$

\section{B. The non Obstante Clause and the Deeming Provision}

The provincial subject "Property and Civil Rights in the Province" 35 will, in its widest sense, overlap with a number of federal subjects, such as banking, patents, copyrights, bankruptcy, bills of exchange and promissory notes, inland fisheries, and other federal works and undertakings, creating the potential for conflict. What prevents conflict from occurring is (1) the exclusivity principle articulated in the preambles to sections 91 and 92, which ensures mutually exclusive spheres that are, by definition, distinct, in conjunction with (2) the well-established canons of construction that statutory and constitutional provisions be read harmoniously with one another, ${ }^{36}$ and that general provisions must yield to specific provisions where there is a conflict. ${ }^{37}$ As such, if a law could be described as coming within property and civil rights but also within banking, the conflict would be resolved in favour of banking, as it is the more specific power. "Property and Civil Rights in the Province" is thus interpreted harmoniously with "Banking" to exclude matters that come within banking. The corollary is that the interpretation of banking needs to remain relatively confined so that it does not override legitimate provincial authority under the property and civil rights power.

Naturally, this operates in the same fashion where the provincial power is the more specific one. ${ }^{38}$ As an example, the Constitution Act, 1867 gives Parliament the power over marriage and divorce (section 91(26)) while the provinces have the power over the solemnization of marriage (section 92(12)). Should Parliament pass a law dealing with the solemnization of marriage, the law would be ultra vires notwithstanding that it does, in a general sense, deal with marriage and divorce. In light of the potential conflict, the phrase "marriage and divorce" must be interpreted to exclude the "solemnization of marriage" so that the two provisions can coexist harmoniously. ${ }^{39}$

In light of the exclusivity principle, the rules of statutory interpretation would have been sufficient to prevent overlap. However, the framers added two additional safeguards to

Lefroy, supra note 10 at lxiii. See also Risk, supra note 10 at 46 . To be sure, the BNA Act did not create two perfectly autonomous entities. The federal government had power to appoint judges in the provinces, and also the power to disallow and reserve provincial legislation. The latter power is potentially the most offensive to a coordinate sovereignty model; though, as historian Paul Romney has argued, disallowance was very much a leftover from colonial times and was only intended to be wielded "in the last resort" (Paul Romney, Getting It Wrong: How Canadians Forgot Their Past and Imperilled Confederation (Toronto: University of Toronto Press, 1999) at 95 [Romney, Getting It Wrong]). More importantly, disallowance was the power of the Governor General, and thus of the Prime Minister. It did not provide Parliament with the power to enact legislation of its own regarding that subject, and thus, did not undermine the exclusivity of the spheres.

Constitution Act, 1867, supra note 7, s 92.

Citizens Insurance Company of Canada v Parsons, [1881] UKPC 49, [1881] 7 AC 96 at 108-109 [Parsons]. See also Doucet-Boudreau v Nova Scotia (Minister of Education), 2003 SCC 62, [2003] 3 SCR 3 at para 50; Montréal (City) v Quebec (Commission des Droits de la Personne et des Droits de la Jeunesse), 2008 SCC 48, [2008] 2 SCR 698 at para 57.

37 This canon of construction is known in Latin as generalia specialibus non derogant. See Century Services Inc v Canada (Attorney General), 2010 SCC 60, [2010] 3 SCR 379 at paras 126-27. See also Toronto Corporoation v Roman Catholic Separate School Trustees, [1925] UKPC 79, [1926] AC 81 at 87-88. See also Browne, Judicial Committee, supra note 29 at 79, 161.

Parsons, supra note 36 at $108-109$.

See WR Lederman, "The Concurrent Operation of Federal and Provincial Laws in Canada" (1963) 9:3 McGill LJ 185 at 187 . See also Parsons, ibid. 
ensure that the broad provincial powers concerning property and civil rights and matters of a merely private or local nature did not come into conflict with or override Parliament's powers under section 91 (including the federal works and undertakings set out in section 92(10), which were incorporated into the enumerated powers in section 91 by virtue of section 91(29)). These are, respectively, the non obstante clause and the deeming provision. ${ }^{40}$

The non obstante clause appears in the preamble to section 91: "[I]t is hereby declared that (notwithstanding anything in this Act) the exclusive Legislative Authority of the Parliament of Canada extends to all Matters coming within the Classes of Subjects next hereinafter enumerated." ${ }^{41}$

Section 91 follows with an enumeration of the federal subjects and concludes with the following paragraph: "And any Matter coming within any of the Classes of Subjects enumerated in this Section shall not be deemed to come within the Class of Matters of a local or private Nature comprised in the Enumeration of the Classes of Subjects by this Act assigned exclusively to the Legislatures of the Provinces." ${ }^{\prime 2}$

The non obstante clause and the deeming provision were effectively an afterthought, inserted, as the Privy Council would later observe (in regard to the deeming provision), "from abundant caution." 43 They did not appear in the original Quebec Resolutions or in any draft of the BNA Act, including the "final draft" (though, as we shall see, a deeming provision applying to property and civil rights appeared in several of the drafts). ${ }^{44}$

The Quebec Resolutions had granted the provinces broad power to make laws respecting "Property and civil rights, excepting those portions thereof assigned to the General Parliament." ${ }^{45}$ Resolution 43(18) also granted the provinces a residual power to make laws regarding "all matters of a private or local nature, not assigned to the General Parliament."46 This language survived the London Resolutions and the first draft of the BNA Act. Then, in the second draft, dated 23 January 1867, the language underwent some important alterations.

The scheme of this legislation, as expressed in the first branch of sect. 91, is to give to the dominion parliament authority to make laws for the good government of Canada in all matters not coming within the classes of subjects assigned exclusively to the provincial legislature. If the $91 \mathrm{st}$ section had stopped here, and if the classes of subjects enumerated in sect. 92 had been altogether distinct and different from those in sect. 91, no conflict of legislative authority could have arisen. The provincial legislatures would have had exclusive legislative power over the sixteen classes of subjects assigned to them, and the dominion parliament exclusive power over all other matters relating to the good government of Canada. But it must have been foreseen that this sharp and definite distinction had not been and could not be attained, and that some of the classes of subjects assigned to the provincial legislatures unavoidably ran into and were embraced by some of the enumerated classes of subjects in sect. 91; hence an endeavour appears to have been made to provide for cases of apparent conflict; and it would seem that with this object it was declared in the second branch of the 91 st section, "for greater certainty, but not so as to restrict the generality of the foregoing terms of this section" that (notwithstanding anything in the Act) the exclusive legislative authority of the parliament of Canada should extend to all matters coming within the classes of subjects enumerated in that section. With the same object, apparently, the paragraph at the end of sect. 91 was introduced, though it may be observed that this paragraph applies in its grammatical construction only to No. 16 of sect. 92 .

Constitution Act, 1867, supra note 7, s 91 [emphasis added].

Ibid [emphasis added].

Alberta (AG) v Canada (AG), [1943] UKPC 5, [1943] AC 356 at 370.

Browne, Documents, supra note 15 at 258-59, 286, 293, 324-26.

Ibid at 161 [emphasis added].

Ibid [emphasis added]. 
The property and civil rights power was amended to read "Property and Civil Rights in the Province" (thereby removing the subordinate clause referring to federal powers). ${ }^{47}$ At the same time, a concluding paragraph was added to the federal powers, the first iteration of what eventually became the deeming provision: "And any Matter coming within any of the Classes of Subjects enumerated in this Section shall not be deemed to come within the Subject of Property and Civil Rights comprised in the enumeration of the Classes of Subjects by this Act assigned exclusively to Provincial Legislation." 48

The 23 January 1867 draft also included a substantive amendment to the provincial residuary power. The power to make laws respecting "all matters of a private or local nature" was changed to read: "Such other Classes of Subjects (if any) as are from Time to Time added to the Enumeration in this Section by any Act of the Parliament of the United Colony." "49 This represented a marked departure from the scheme the Fathers of Confederation had agreed upon at Quebec and that had been subsequently ratified by the Province of Canada and, in principle, by Nova Scotia and New Brunswick. Gone was the broad residuary power in favour of the provinces that had been incorporated into the Quebec Resolutions, and in its place stood little more than an affirmation of provincial subordination. ${ }^{50}$ Likely for this reason, the change was resisted. ${ }^{51}$

The language of the Quebec Resolutions reappeared in the next draft, but in the "final draft" dated 9 February 1867, the framers went back to the language of the January 23 draft, including the drastically diminished provincial residuary power. ${ }^{52}$ Then, in the final bill that became law, the framers reinstated the broad provincial residuary power, but now without the subordinate clause. The deeming provision was incorporated in place of the subordinate clause, and the framers also added the non obstante clause, which ensured that the broad property and civil rights power, no longer containing its own subordinate clause, would not consume the specific enumerations in sections 91 and 92(10). Thus, while the style and prose of the BNA Act bore little more than a passing resemblance to the Quebec Resolutions, in substance it honoured the agreement reached at Quebec: the provinces retained broad powers over property and civil rights and matters of a private or local nature, but these powers excluded "those portions thereof" assigned to Parliament. ${ }^{53}$

Scholars have traditionally agreed that the non obstante clause renders Parliament's powers "paramount," 54 such that if a matter could be described as coming within both

Ibid at 258 .

Ibid at 259 [emphasis added].

Ibid at 258 .

This draft also referred to provincial legislation as mere "Ordinance[s]" (ibid at 258). See also Paul Romney, "Why Lord Watson Was Right," in Janet Ajzenstat, ed, Canadian Constitutionalism: 17911991 (Ottawa: Canadian Study of Parliament Group, 1992) 177 at 189.

51 Romney, ibid. Romney cites Hector Langevin's letters from London for the proposition that he was constantly on guard against the centralizing pressures from the other framers: see Andrée Désilets, Hector-Louis Langevin: Un Père de la Confédération Canadienne (1826-1906) (Montreal: Presses de l'Université Laval, 1969) at 164-67. In Romney, Getting It Wrong, supra note 34, he argues convincingly that that the centralizing vision of men like Macdonald was tempered by strong decentralizing forces that came not only from Quebec and the Maritimes, but also from Ontario, as exemplified by former Ontario Premier Oliver Mowat.

Browne, Documents, supra note 15 at 286, 293, 324-26.

Ibid at 161 .

This is distinct from the paramountcy doctrine, which deals with operational conflicts between two pieces of valid legislation. 
sections 91 and 92, the issue will be resolved in favour of section $91 .^{55}$ However, this primacy is not of much practical significance since the exclusivity principle and the rules of statutory interpretation already ensure that the potentially overlapping grants of power in sections 91 and 92 are interpreted to exclude one another. Thus, as mentioned above, while Parliament's "marriage and divorce" power may supersede the provincial power over the solemnization of marriage, it is a moot point since "marriage and divorce" is construed to exclude "the solemnization of marriage."

To take another example, it is certainly the case that Parliament may pass laws for the peace, order and good government of Canada "notwithstanding" the enumerations in section 92 - and it was for this reason that O'Connor argued in his 1939 Report that POGG ought

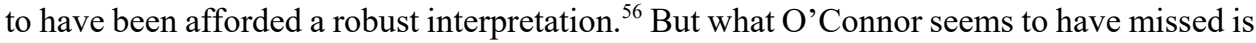
that POGG's technical primacy does not increase its content or scope. The preamble states that Parliament may pass laws for the peace, order, and good government of Canada in relation to matters not "assigned exclusively" to the provinces. As the most general power relative to the enumerations in section 92, the content and scope of POGG will therefore exclude the more specific enumerations in section 92. Beyond that, the POGG residuary power must necessarily be confined to matters that are not already enumerated in section 91 . Thus, a proper interpretation of the POGG power based on the ordinary canons of construction would yield a narrow and truly "residual" power restricted to matters that are, in the words of Lord Watson, "unquestionably of Canadian interest and importance."

To summarize, the non obstante clause and the deeming provision do not disrupt the balance of power between Parliament and the provincial legislatures. They simply reinforce the mutual exclusivity of jurisdiction and ensure that the general provincial powers over property and civil rights and matters of a merely local or private nature do not come into conflict with or override the specific powers enumerated in sections 91 and 92(10).

\section{Concurrent Powers}

At the Quebec Conference, the Fathers had agreed that agriculture and immigration would be subject to concurrent jurisdiction. ${ }^{58}$ The Quebec Resolutions listed agriculture and immigration in both Resolutions 29 and $43,{ }^{59}$ but no express distinction was drawn between

See O'Connor Report, supra note 32; Browne, Judicial Committee, supra note 29. O'Connor and Browne agreed that the deeming provision only applied to section 92(16) and that federal primacy was thus vested in the non obstante clause. They differed as to whether the non obstante clause applied only to the enumerata or whether it also applied to POGG, with Browne arguing the former and O'Connor arguing the latter.

56 O'Connor Report, ibid at 25, 43-44, 47. For O'Connor, the Privy Council's great misstep was its focus on and misinterpretation of the deeming provision. By concluding that the deeming provision applied to all sixteen provincial powers, as opposed to 92(16) alone, the Privy Council had grounded federal primacy in the deeming provision and had effectively ignored the non obstante clause in so doing. The problem with this approach was that the deeming provision only gave primacy to the federal enumerata, not to POGG. Thus, by grounding federal primacy in the deeming provision and misreading the non obstante clause, the Privy Council had marginalized the importance of POGG, which, according to O'Connor, should also have been treated as paramount. It was for this reason that O'Connor assailed the Privy Council as an "Imperial judicial tribunal" dedicated to the protection of provincial autonomy rather than the proper application of the text, which he considered to be centralist in character (ibid at 25).

Ontario (AG) v Canada (AG), [1896] UKPC 20, [1896] AC 348 at 360-61.

Browne, Documents, supra note 15 at 119-20.

Ibid at $159-60$. 
them and the exclusive powers. It was left to the keen reader to discern whether a power was exclusive or concurrent.

The framers of the BNA Act recognized that the concurrent powers would need to be severed from the exclusive ones, so that there would be no ambiguity with respect to which was which. The first draft of the Act granted the provinces exclusive power over the enumerated subjects "with the exception of Agriculture and Immigration, in regard to which Parliament shall have concurrent jurisdiction." 60 The final version of the BNA Act went one step further, creating an entirely separate section for agriculture and immigration - section 95. Severing agriculture and immigration in this fashion allowed the framers to incorporate more exclusivist language throughout sections 91 and 92 . Thus, by emphasizing the concurrency of agriculture and immigration in section 95 , the framers were also emphasizing the exclusivity of the other powers.

Section 95 stipulates that both the provincial legislatures and Parliament may pass laws in relation to agriculture and immigration, and further specifies that a provincial law shall only operate so long as it is not "repugnant" to the federal law. ${ }^{61}$ In other words, section 95 provides for federal paramountcy in cases of operational conflict. The paramountcy clause was adapted from Resolution 45 at the Quebec Conference, which states: "In regard to all subjects over which jurisdiction belongs to both the General and Local Legislatures, the laws of the General Parliament shall control and supersede those made by the Local Legislature, and the latter shall be void so far as they are repugnant to or inconsistent with the former." ${ }^{2}$

That the Fathers of Confederation would recognize the necessity of including a paramountcy clause in respect of the concurrent powers but not in respect of the exclusive powers suggests that they did not conceive of any overlap occurring in respect of the latter. At the Quebec Conference, they had devised a division of powers based on exclusive jurisdictional spheres (with the exception of agriculture and immigration), and in framing the BNA Act, they had made the necessary textual modifications to ensure that exclusivity.

\section{Pith and Substance And Legitimate OverlaP}

The preambles to sections 91 and 92 contain another important modification from the Quebec Resolutions to help ensure jurisdictional exclusivity. The Quebec Resolutions had granted Parliament and the provinces the authority to make "[1]aws respecting the following subjects. ${ }^{, 63}$ This language remained intact in the first draft of the BNA Act. ${ }^{64}$ It was not until the next draft of 23 January 1867 that the language was amended to give each order the authority to make laws "in relation to Matters coming within the Classes of Subjects" enumerated. The substitution of this phrase provided yet another safeguard against jurisdictional overlap. If we take the example of "banking" enumerated in section 91(15), a "law respecting" banking could have been interpreted narrowly to mean that the law's purpose must be directed at the regulation of banking, and perhaps an essential component 
of banking. By contrast, a law "in relation to a matter coming within" the subject of banking is far broader. It creates additional distance between the law and the subject, and therefore allows for a more indirect relationship. It guarantees not only that the orders are precluded from targeting one another's jurisdiction, but also that the effects of the law must be contained to each order's jurisdictional sphere (save and except for incidental effects). This is what is commonly known as the "pith and substance" doctrine, whereby a court must examine not only a law's purpose, but also its effects.

This section discusses the way in which the pith and substance doctrine ought to be applied in accordance with the text of the Constitution. I argue that the modern doctrine of interjurisdictional immunity is misunderstood, and is actually a function of the pith and substance doctrine in circumstances where a provincial law governing property and civil rights in the province purports to apply to federal undertakings situated there. If the provincial law, as applied to a federally regulated undertaking, is "in relation to a matter coming within" that undertaking, then the law is ultra vires to the extent of the application and should be properly read down. Where the law does not come within section 91, however, and only incidentally affects the undertaking, then this degree of overlap is permissible. I also discuss the double aspect doctrine, which I argue is perfectly consistent with the exclusivity principle (and the pith and substance doctrine in particular), provided the impugned law is truly in relation to a valid matter and does not come within the other order's jurisdiction. Finally, I argue that the exclusivity principle can accommodate limited ancillary powers. Where a statutory provision lies outside an order's jurisdiction, the law should only be upheld where it is necessarily incidental to an otherwise valid statute. In my respectful view, the "rational functional connection" approach is directly contrary to the exclusivity principle.

\section{A. INTERJURISDICTIONAL IMMUNITY}

Under a proper application of the pith and substance doctrine, it may be possible for a law to be in relation to two matters, one federal and the other provincial. Such a law could have a bona fide purpose, but if the law is also "in relation" to a matter coming within the other order's jurisdiction, the law is ultra vires to the extent of the infringement. This situation arises where a province has passed a generally valid law under the property and civil rights power that purports to apply to all works or undertakings ${ }^{65}$ in the province (for example, labour or employment legislation), including federally regulated works and undertakings situated in the province. The provinces (and Parliament for that matter) cannot do indirectly what they are not permitted to do directly, ${ }^{66}$ and so where an undertaking lies outside provincial jurisdiction, a province cannot legislate in respect of that undertaking under the banner of legislating in respect of local undertakings or property and civil rights generally. As Justice Beetz explained in Bell Canada v. Quebec (Commission de la Santé et de la Sécurité du Travail), the exclusivity principle is "absolute" and it matters not whether the

65 Works and undertakings essentially refer to businesses or industries. Works are "physical things, not services" whereas an undertaking "is not a physical thing, but is an arrangement under which of course physical things are used" (Re Regulation and Control of Radio Communication in Canada, [1932] UKPC 7, [1932] AC 304 at 315). Section 92(10) grants the provinces the power to regulate local works and undertakings, but there are a number of particular works and undertakings that are placed under federal control, which are enumerated under section 92(10) as well as under various heads in section 91. See Propositions 32 and 34 in Lefroy, supra note 10 at 372-73. 
provincial law at issue seeks to target a federal undertaking or whether a generally applicable law simply affects a vital aspect of the undertaking. ${ }^{67}$

The courts traditionally dealt with this phenomenon by "reading down" the statute construing it, in other words, so as not to apply to federal undertakings and thus only "come within" the property and civil rights power. ${ }^{68}$ This well-accepted canon of construction ${ }^{69}$ allows for legislation that is broadly within the province's sphere to continue to operate while preventing incursions upon Parliament's exclusive jurisdiction. In recent decades, however, the Supreme Court has begun speaking of the "doctrine of interjurisdictional immunity." Interjurisdictional immunity is said not to concern the validity of a law, only its applicability. ${ }^{70}$ Rather than declare a law to be ultra vires to the extent that it infringes on a federal work or undertaking, interjurisdictional immunity deems the work or undertaking in question to be "immune" from the application of the law. This should be a distinction without a difference, but in practice, the introduction of the interjurisdictional immunity doctrine has confused matters, as it is generally portrayed as an exception to, rather than a proper application of, the pith and substance doctrine.

The term "interjurisdictional immunity" did not appear in a Supreme Court of Canada decision until 1987..$^{71}$ The original Company Law Cases, ${ }^{72}$ which are held up as the genesis of the interjurisdictional immunity doctrine, never employed the term, nor was there any suggestion in these decisions that the traditional pith and substance approach was inapplicable. In each case the issue was substantially the same: whether a provincial law passed broadly to deal with property and civil rights was ultra vires because it interfered with the federal power to incorporate companies with federal objects, and thus, "came within" section 91. In Great West Saddlery, for example, the Privy Council affirmed the decision of the lower court that the "pith and substance" of the impugned provisions, "as applied to Dominion companies, was to preclude them from the exercise of some of their powers." The Privy Council concluded that the provisions must be declared ultra vires since they were not "directed solely to the purposes specified in s. 92."74 Thus, under the "pith and substance" approach, the law was found to be in relation to two matters, one of which came within

[1988] 1 SCR 749 [Bell Canada (1988)] (“"t] he particular effect of general provincial laws that would result from their application to federal undertakings would, in the case at bar, constitute an encroachment on the exclusive jurisdiction of Parliament" at 841).

68 Dick v The Queen, [1985] 2 SCR 309 at 322:

The Wildlife Act does not differ in this respect from a great many provincial labour laws which are couched in general terms and which, taken literally, would apply to federal works and undertakings. So to apply them however would make them regulate such works and undertaking under some essentially federal aspects. They are accordingly read down so as not to apply to federal works and undertakings.

69 See Manitoba (Attorney General) v Metropolitan Stores Ltd, [1987] 1 SCR 110 at 125:

Still another meaning of the "presumption of constitutionality" is the rule of construction under which an impugned statute ought to be construed, whenever possible, in such a way as to make it conform to the Constitution. This rule of construction is well known and generally accepted and applied under the provisions of the Constitution relating to the distribution of powers between Parliament and the provincial legislatures. It is this rule which has led to the "reading down" of certain statutes drafted in terms sufficiently broad to reach objects not within the competence of the enacting legislature.

AHRA Reference, supra note 3 at para 188.

OPSEU, supra note 4 at 16-20 is the first Supreme Court decision to mention the doctrine.

John Deere Plow Company Limited v Wharton, [1914] UKPC 87, [1915] AC 330 [John Deere Plow]; Great West Saddlery Co v The King, [1921] UKPC 27, [1921] 2 AC 91 [Great West Saddlery]; Manitoba (AG) v Canada (AG), [1928] UKPC 103, [1929] AC 260. 
Parliament's exclusive jurisdiction, and was therefore ultra vires. The Supreme Court continued to apply this same reasoning for decades, notably in Reference Re Minimum Wage Act of Saskatchewan, ${ }^{75}$ and Commission du Salaire Minimum v. Bell Telephone Co. of Canada. $^{76}$

In more recent decisions, however, the Supreme Court has turned to the doctrine of interjurisdictional immunity and has severed this doctrine from the ordinary pith and substance approach. In treating interjurisdictional immunity as the "undertow" against the "dominant tide" of pith and substance, ${ }^{77}$ the Supreme Court has consequently deemed it to have "limited scope." ${ }^{78}$ Following the Supreme Court's decision in Canadian Western Bank, a law passed by a province will only be deemed inapplicable to a federal undertaking where it "impairs" the "core" of a subject coming within Parliament's jurisdiction. ${ }^{79}$ This is a difficult test to apply in practice, since reasonable people can disagree over what belongs at the "core" of a given subject and whether the level of intrusion rises to the level of "impairment." More importantly, this is not what the text says. So long as a provincial law is "in relation to a matter coming within" a federal power, that law must either be struck down or read down.

The "core impairment" test has also confused matters by suggesting the existence of a reciprocal provincial doctrine of interjurisdictional immunity. ${ }^{80}$ After all, if the core of each federal power is immune to provincial intrusion, should it not also be the case that the core of each provincial power is similarly immune to federal legislation? The desire for a reciprocal doctrine is certainly understandable, but it proceeds from a basic misunderstanding of what the doctrine of interjurisdictional immunity is and why it was developed in the first place. As discussed above, interjurisdictional immunity is, in fact, not an independent doctrine at all, but rather an application of the pith and substance doctrine. It addresses the unique relationship between the property and civil rights power and the specific federal works and undertakings set out in sections 91 and 92(10). In its widest sense, the concept of "property and civil rights" could be interpreted to encompass these federal works and undertakings; or, to put it another way, these federal works and undertakings could each be classified as a species or subset of property and civil rights. It is for this reason that broad provincial laws passed under the property and civil rights power must be read down.

By contrast, there are very few provincial powers that could be said to be a species or subset of a more general federal power. The solemnization of marriage and direct taxation

(1947), [1948] SCR 248. In that case, Chief Justice Rinfret concluded that the Act was either meant to exclude postal workers, or "if it is intended to apply to His Majesty in right of the Dominion, it is ultra vires" (ibid at 254). Justice Taschereau similarly concluded in his concurring opinion "that the fixing of the wages of the Postal employees, is a matter in pith and substance 'Postal Service Legislation', upon which the provinces may not legislate without invading a field 'exclusively' assigned to the Dominion" (ibid at 257).

$76 \quad$ 1966] SCR 767 [Bell Canada (1966)] ("regulation of the field of employer and employee relationships in an undertaking such as that of the respondent's, as in the case of the regulation of the rates which they charge to their customers, is a 'matter' coming within the class of subject defined in s. 92(10)(a) and, that being so, is within the exclusive legislative jurisdiction of the Parliament of Canada" at 777). OPSEU, supra note 4 at 18.

Canadian Western Bank, supra note 4 at para 52.

Ibid at 48 .

Ibid at para 35. See also Michelle Biddulph, "Shifting the Tide of Canadian Federalism: The Operation of Provincial Interjurisdictional Immunity in the Post-Canadian Western Bank Era" (2014) 77:1 Sask L Rev 45. 
for a provincial purpose are likely the only two contenders, and it will be a rare case where Parliament passes a generally valid law under its marriage and divorce or taxation powers, which would then need to be read down so as to exclude the more specific provincial powers. $^{81}$

Thus, while a reciprocal provincial doctrine of interjurisdictional immunity is not theoretically impossible, the concept is unhelpful and likely only to confuse matters further. The purpose of the doctrine of interjurisdictional immunity is not to keep the core of certain powers "immune" from regulation, but rather to ensure that a law is construed sufficiently narrowly so that it remains, in pith and substance, intra vires. The sure way of protecting provincial powers from intrusion is not through a reciprocal doctrine of interjurisdictional immunity, but rather from a rigorous application of the exclusivity principle in the context of a pith and substance analysis.

To summarize, the concept of interjurisdictional immunity is entirely sound, provided it is properly treated as being a function of, not an exception to, the basic pith and substance approach. To this end, rather than attempting to define the "core" of a given power and then determining whether the law "impairs" that power, the Supreme Court should simply examine whether the law amounts to a real regulation of the federal work or undertaking. The inquiry should concern whether the law amounts to a regulation of the "work qua work," 82 meaning that it targets or affects an integral aspect of the work or undertaking. If so, then the law is "in relation" to that matter and is thus ultra vires. If, however, the law is merely a law of general application that incidentally affects the work or undertaking, then the law is, in pith and substance, intra vires, ${ }^{83}$ since it is not "in relation to a matter coming within" the other order's jurisdiction. ${ }^{84}$

\section{B. DOUble ASPECT}

The exclusivity principle does not preclude the possibility of any overlap whatsoever. Beyond allowing for incidental effects, as discussed above, the exclusivity principle can also accommodate "double aspects." As the O'Connor Report rightly pointed out, the Constitution Act, 1867 does not grant either order of government legal jurisdiction over things, but only legislative authority over matters coming within the enumerated subjects. ${ }^{85}$ An "automobile" is neither a matter nor an enumerated subject, and so there is nothing at the outset that would logically preclude both orders of government from legislating in respect

81 It has been argued that under a provincial interjurisdictional immunity doctrine, the core of provincial powers would be immune from the criminal law power (see Biddulph, ibid at 59-60). This, however, misunderstands the criminal law power. As discussed below, the criminal law power is not a general power encompassing more specific powers in section 92. It is conceptually distinct from the other powers and thus does not truly overlap with the powers enumerated in section 92, provided its interpretation is confined to the suppression of evils rather than the regulation of goods.

Ontario Hydro v Ontario (Labour Relations Board), [1993] 3 SCR 327 at 363 [Ontario Hydro].

Quebec (Attorney General) v Lacombe, 2010 SCC 38, [2010] 2 SCR 453 at para 36 [Lacombe].

Admittedly, determining whether the effect of the law is merely "incidental" will rest on some degree of subjectivity, but this potential for uncertainty pales in comparison to the intellectual gymnastics required to define a core impairment. The incidental effects doctrine has deep roots in Canadian constitutional doctrine, and is essentially a corollary to the pith and substance doctrine (and by extension, the proper application of the doctrine of interjurisdictional immunity). It can thus be applied with relative predictability. 
of automobiles. In practice, the vast majority of legislation relating to automobiles will deal with automobiles as private property or as a commercial item, and as such, will concern a matter that comes within the province's power over property and civil rights. On the other hand, no one would doubt that Parliament possesses the power to criminalize an individual's use or operation of an automobile while impaired by alcohol or drugs.

The double aspect principle is largely a function of the uniqueness of the criminal law power. ${ }^{86}$ Most of the subjects in sections 91 and 92 concern the regulation of societal "goods" such as tangible property, commercial conduct, and particular works and undertakings. The criminal law power, by contrast, is a particular type of legislation that engages virtually every facet of society and is aimed at the suppression of evils. It is therefore conceptually distinct. A province can outlaw drinking and driving as part of its larger power to regulate the use of automobiles on public highways. Parliament, conversely, can outlaw drinking and driving because of the evil it presents: unsafe streets and an increased likelihood of serious injury or death. These laws will seem similar at first glance, but there will be some distinct differences. The criminal law, if properly enacted, will not be part of a larger regulatory scheme governing the use of automobiles on public highways; it will simply impose a prohibition and a penalty. The criminal law's penalty will also likely include a potential prison sentence; conversely, the provincial law's penalty will likely be less punitive - in most cases, a fine and a license suspension. As such, the criminal statute will not be in relation to a "matter" coming within the provincial jurisdiction over property and civil rights (the safe regulation of highway traffic), and the provincial highway law will not be in relation to a matter coming within Parliament's jurisdiction over the criminal law (the outlawing of dangerous and harmful conduct).

This overlap can be contrasted with the labour relations example cited above. A province's labour relations statute might differ with its federal counterpart in the details, but its overall character will be exactly the same - the regulation of employer-employee relations. A provincial statute that purports to apply to all workers in the province would necessarily include federally regulated workers - for example, those employed in the postal service. The provincial statute would not deal with a "double aspect" of "the postal service"; it would engage the very same aspect as the federal statute, the regulation of employer-employee relationships in the postal service. The law would thus be in relation to a matter coming within the province's exclusive jurisdiction (employer-employee relations generally) and a matter coming within Parliament's exclusive jurisdiction (employer-employee relations in the postal service), and would properly be read down as a result. Put succinctly, a thing may

The original "double aspect" cases, which dealt with liquor licensing and prohibition, are believed to have concerned the federal POGG power. However, in Russell $v$ The Queen, [1882] UKPC 33, [1882] 7 AC 829 [Russell], which established the federal power to enact temperance legislation, it is arguable that the impugned legislation was actually grounded in the criminal law power, not the POGG power. While the Privy Council made reference to the fact that the statute was passed for the "order and good government of Canada" it added that the legislation has a "direct relation to criminal law" (ibid at 839 [emphasis added]). The Court stated that the purpose of the legislation was the order and safety of the Dominion, which is a traditional criminal law purpose. The belief that Russell was decided on the basis of POGG likely flowed from the Privy Council's later embrace of the "three compartment" approach, discussed above in Part II.A, which viewed POGG as a completely distinct class of power. In Russell, the Privy Council appears to have worked under the "two compartment" approach, in which the criminal law power was not distinct from POGG, but was rather an illustration of POGG. 
have two genuine aspects, but a law may not relate to two matters where one comes within section 91 and the other within section 92 .

There is no absolute rule that overlap can only exist where one of the subjects at issue is the criminal law; but more often than not this will be the case. ${ }^{87}$ The criminal law, by its very nature, will tend to overlap with the regulation of property or undertakings. The key is that the two laws will not "look" the same; they will truly deal with different aspects of the thing and will therefore be able to peacefully coexist, the former suppressing an evil and the latter regulating a good. ${ }^{88}$ Where the criminal law is not involved, a genuine double aspect becomes more difficult to justify.

\section{AnCILlary PoWers}

While this is not expressly contemplated by the text of sections 91-95, cases are likely to arise where the pith and substance of a particular provision of an otherwise valid statute comes within the jurisdiction of the other order. When this occurs, the exclusivity principle must be balanced against the order's basic authority to pass legislation under a valid head of power. The Privy Council struck this balance well by way of the "necessarily incidental" test. ${ }^{89}$ That is, the impugned provision must be incidental to the overall scheme and necessary for the valid legislation to be effective. This is a tough hurdle to overcome, and it ensures that the incursion upon an order's jurisdiction will be limited to those instances that are absolutely necessary to give effect to an otherwise valid law. ${ }^{90}$

In recent decades, as part of the trend toward a more "flexible" approach to the division of powers, the strict necessity standard has been relaxed beyond what the text of the Constitution Act, 1867 can reasonably bear, and the scope of the "ancillary powers" doctrine has been unduly expanded. Under the test developed by the Supreme Court in General Motors of Canada Ltd. v. City National Leasing, ${ }^{91}$ courts must now first determine whether the ultra vires provision amounts to a "serious" intrusion. If so, then the necessarily incidental test still applies. If the intrusion is deemed to be mild, however, then the court should uphold the provision so long as it has a "rational, functional connection" to the valid scheme, meaning that it is "sufficiently integrated." 92 This approach is clearly inconsistent with the exclusivity principle and opens the door to unwarranted intrusions upon an order's exclusive jurisdiction (usually by Parliament against the provinces, since the ancillary powers doctrine typically arises where a federal provision comes within the provincial power over property and civil rights). In an era of increasingly complex legislative schemes, the modern

Bell Canada (1988), supra note 67 at 765-66.

See Lefroy, supra note 10 at 354-55.

Canada (AG) v Quebec (AG), [1946] UKPC 43 [1947] AC 33 at 43.

See e.g. Canada (AG) v British Columbia (AG), [1929] UKPC 80, [1930] AC 111, where the Privy Council dealt with a federal law that imposed license requirements on the operation of fish canneries. Parliament argued that such a licensing scheme, which would typically fall under provincial jurisdiction, was necessarily incidental to legislation validly enacted under the federal power over "Sea Coasts and Inland Fisheries" (see Constitution Act, 1862, supra note 7, s 91(12)). The Privy Council disagreed, noting that a "necessary connection" between effective fisheries legislation, on the one hand, and the licensing scheme enacted by Parliament, on the other, had not been firmly established (ibid at 122 [emphasis added]).

91 [1989] 1 SCR 641 [General Motors].

92 Ibid at 671-72; Lacombe, supra note 83 at paras 3, 41-42. 
incarnation of the ancillary powers doctrine has the serious potential to undermine the constitutional division of powers.

This judicial overreach could perhaps be forgiven if it produced doctrine that could be applied with certainty and predictability. However, the opposite is true. As a matter of interpretive theory, it makes little sense to categorize encroachments (or "overflow" as the Supreme Court now prefers $)^{93}$ as being more or less "serious." For the ancillary powers doctrine to be engaged, there must first be a legislative provision that, in pith and substance, comes within the jurisdiction of the other order. ${ }^{94}$ This necessarily means that the overlap is not merely "incidental," but is, in fact, meaningful. ${ }^{95}$ A provision that comes within the jurisdiction of one order arguably cannot do so "seriously" or "mildly"; it either does or it does not.

What is more, even if the severity of the intrusion could be classified (based on the various factors discussed in General Motors) ${ }^{96}$ why should there be only two classifications - less serious intrusions that warrant a "rational functional connection" approach, and more serious intrusions that call for the necessity approach? If intrusions really are capable of being measured, then surely they would come in various shades of grey and would not be conducive to rigid categorization. Under the General Motors test, however, each intrusive provision will effectively be classified as either serious or not serious and will consequently be assessed under very different tests, one that tends toward exclusivity and the other toward flexibility. Indeed, one could easily conceive of two "somewhat serious" intrusions, one of which is assessed under the rational, functional connection approach, and is upheld, while the other is treated to the more rigorous necessity standard, and is struck down.

Laying aside these theoretical objections, the General Motors test has proven itself to be problematic, if not unworkable, in practice. Ascertaining the severity of an encroachment is an inherently subjective exercise, as the AHRA Reference demonstrated. In that case, the Supreme Court split 4-4 on the issue of which approach under the General Motors test was applicable. The case concerned a federal statute, which had been purportedly enacted under the criminal law power, dealing with various issues concerning assisted human reproduction. A number of the provisions were regulatory in nature and clearly came within the provincial powers over property and civil rights and matters of a merely local or private nature. Chief Justice McLachlin, writing for four of the justices, concluded that these provisions did not significantly intrude upon the provincial sphere and thus, the rational functional connection test should apply. ${ }^{97}$ Justices LeBel and Deschamps, on behalf of four other justices, disagreed, finding that the "overflow is serious" 98 and thus, the necessarily incidental test was applicable.

AHRA Reference, supra note 3 at para 188 .

Lacombe, supra note 83 at para 36.

Indeed, this is what distinguishes the ancillary powers doctrine from the doctrine of incidental effects. See ibid.

96 AHRA Reference, supra note 3 at paras 128-32. These factors include, but are not necessary limited to, (1) the scope of the heads of power in play (whether they are broad or narrow); (2) the nature of the impugned provision (whether it is a substantive part of the Act); and (3) whether the enacting body has a history of legislating on the matter in question.

$97 \quad$ Ibid at paras 135-37.

Ibid at para 275 . 
Not surprisingly, applying these two very different tests led to opposite results - Chief Justice McLachlin would have upheld the provisions on the basis that they were rationally and functionally connected to the overall scheme, while Justices LeBel and Deschamps would have struck down the provisions on the basis that they were not necessary for the scheme to function. It was therefore left to Justice Cromwell to cast the deciding vote in respect of each impugned provision. In the end, the Supreme Court handed down an awkward decision, whose divisions arose, at least in part, from the unworkability of the General Motors test.

Incidentally, Chief Justice McLachlin's opinion acknowledged that the test has faced criticism, but stated that "it need not be revisited" for the purposes of the decision. ${ }^{99}$ This raises an important question: if the Supreme Court is not prepared to revisit the viability of a doctrine in the midst of a deeply fractious decision, then with respect, when would it actually be prepared to do so?

\section{GetTing BACK TO THE WORDS}

Lord Sankey will forever be associated with the phrase "living tree," a metaphor that he used to describe Canada's constitutional order in the famous Edwards ${ }^{100}$ decision (better known to many as the Persons case). ${ }^{101}$ However, two years later he offered another analogy that, while far less known and cited, is no less relevant. In the Aeronautics Reference, ${ }^{102}$ Lord Sankey warned against judicial interpretations moving slowly but surely away from the original meaning of the text — "from what has been enacted to what has been judicially said about the enactment"

To borrow an analogy; there may be a range of sixty colours, each of which is so little different from its neighbour that it is difficult to make any distinction between the two, and yet at the one end of the range the colour may be white, and at the other end of the range black. Great care must therefore be taken to consider each decision in the light of the circumstances of the case in view of which it was pronounced, especially in the interpretation of an Act such as the British North America Act, which was a great constitutional charter,

Ibid at para 127.

Edwards v Canada (AG), [1929] UKPC 86, [1930] AC 124 at 136 [Edwards].

It is doubtful that Lord Sankey was conveying anything remotely resembling the modern living tree doctrine - the notion that the meaning of the Constitution should evolve in accordance with modern social and economic values - which did not achieve predominance in Canada until approximately 1980, more than fifty years after Edwards was decided. There is a growing body of scholarship indicating that Edwards was, in fact, a model of traditional textual analysis, and that the "living tree" passage simply meant that Canada's common law and unwritten conventions were capable of evolving independent of Britain. See Bradley W Miller, "Origin Myth: The Persons Case, the Living Tree, and the New Originalism" in Grant Huscroft \& Bradley W Miller, eds, The Challenge of Originalism: Theories of Constitutional Interpretation (Cambridge: Cambridge University Press, 2011) 120. See also Asher Honickman, "The Living Fiction: Reclaiming Originalism for Canada" (2014) 43:3 Adv Q 329 at 334-36; Scott Reid, "The Persons Case Eight Decades Later: Reappraising Canada's Most Misunderstood Court Ruling" (2013) [unpublished], online: Social Science Research Network <https:// papers.ssrn.com/sol3/papers.cfm?abstract id=2209846>; Benjamin Oliphant \& Léonid Sirota, "Has the Supreme Court of Canada Rejected 'Originalism'?” (2016) 42:1 Queen's LJ 107 [Oliphant \& Sirota, "Rejected Originalism"]; Léonid Sirota \& Benjamin Oliphant, "Originalist Reasoning in Canadian Constitutional Jurisprudence" (2017) 50:2 UBC L Rev 505 [Sirota \& Oliphant, "Originalist Reasoning"]. Most recently, Justice Rothstein advanced this argument during a lecture shortly after stepping down from the bench: CollegeOfLawUsask, "Guest Speaker: Mr. Justice Marshall Rothstein" (12 January 2016), online: YouTube $<$ https://www.youtube.com/watch?v=H1gAyklurGs $>$ [Rothstein Lecture].

Supra note 1 .

Ibid at 70 . 
and not to allow general phrases to obscure the underlying object of the Act, which was to establish a system of government upon essentially federal principles. Useful as decided cases are, it is always advisable to get back to the words of the Act itself and to remember the object with which it was passed. ${ }^{104}$

If that were not clear enough, Lord Sankey added that " $[\mathrm{t}]$ he process of interpretation as the years go on ought not to be allowed to dim or to whittle down the provisions of the original contract upon which the federation was founded."105

In recent decades, Canada's federalism jurisprudence has begun to pass through Lord Sankey's "sixty colours." The Supreme Court is gradually, but steadily, "whittl[ing] down the provisions of the original contract" by turning away from the textually-embedded exclusivity principle and toward a flexible model of federalism built upon overlapping jurisdiction.

This trend is arguably inconsistent with the Supreme Court's own stated method of constitutional interpretation. While the Supreme Court has repeatedly affirmed the modern living tree doctrine, it has also continued to recognize "the primacy of the written text of the Constitution," "106 which "promotes legal certainty and predictability" and "provides a foundation and a touchstone for the exercise of constitutional judicial review."107 Constitutional interpretation must always "begin with the language of the constitutional law or provision in question," "108 and "[t]he analysis must be anchored in the historical context of the provision." 109

In a similar vein, the Supreme Court has acknowledged the fundamental importance of constitutionalism and the rule of law in Canada's constitutional order. ${ }^{110}$ As Justice Rothstein said at a recent conference, the rule of law demands, among other things, that judicial decisions be made in accordance with the law. ${ }^{111}$ Under the Constitution Act, $1982,{ }^{112}$ the power to amend the Constitution is given exclusively to the legislative branch. Sections 91 and 92 of the Constitution Act, 1867 similarly state that Parliament and the provincial legislatures have the "exclusive" authority to legislate — a principle "won four centuries ago at the cost of much bloodshed." 113 The role of the judiciary is to decide cases and apply the law. The power to strike down legislation flows from, and is necessarily incidental to, this primary function. At base, it is the application of the supreme law — the Constitution - to

\footnotetext{
104 Ibid [emphasis added].

105 Ibid.

Caron, supra note 6 at para 36. See also Quebec (Attorney General) v Canada (Attorney General), 2015 SCC 14, [2015] 1 SCR 693 [Quebec (AG)] ("[t]he primacy of our written Constitution remains one of the fundamental tenets of our constitutional framework" at para 18). Reference re Secession of Quebec, [1998] 2 SCR 217 at para 53 [Secession Reference]. General); An Act Respecting the Vancouver Island Railway (Re), [1994] 2 SCR 41 at 88 [Vancouver Island Railway $(\mathrm{Re})]$.

$109 \quad R v$ Blais, 2003 SCC 44, [2003] 2 SCR 236 at para 40.

110 Secession Reference, supra note 107 at paras 49, 70-78.

Rothstein Lecture, supra note 101

Constitution Act, 1982, being Schedule B to the Canada Act 1982 (UK), 1982, c 11.

Ishaq $v$ Canada (Citizenship and Immigration), 2015 FCA 151, [2016] 1 FCR 686 at para 26.
} 
inferior laws. ${ }^{114}$ If, in applying the supreme law, judges marginalize the text or alter its meaning, then they alter the law and thereby exceed their own constitutional authority.

This is not to argue that there can be no role for the judiciary in guiding the course of the Constitution to ensure that it remains applicable to modern Canadian society; and indeed, much ink has been spilled on how an "originalist" approach to constitutional interpretation may be qualified by modest judicial interventions. ${ }^{115}$ My aim here is not to advance that discussion, but to simply state that if the text is indeed of primary importance as the Supreme Court has said, then that primacy requires, at a minimum, the courts to develop judicial doctrine with a close eye to constitutional language and structure.

Admittedly, some degree of deviation from the text is unavoidable due to two firmly entrenched interpretive principles: the presumption of constitutionality ${ }^{116}$ and stare decisis. The presumption of constitutionality is premised on the theory of judicial restraint. A democratically elected legislature is presumed to have considered the Constitution before enacting a given law, and is thus presumed to be acting in accordance with the Constitution. ${ }^{117}$ Where one of the orders has passed a law that clearly lies outside its legislative authority, it is imperative for the courts to strike it down; but where the law is merely of questionable constitutionality, the courts strive to adopt a deferential posture. The second principle, stare decisis, holds that past decisions should be upheld, even where the result was questionable, to foster certainty and predictability and to ensure a continuity of

See Marbury v Madison, 5 US 137 (1803) ("[i]f then the courts are to regard the constitution; and the constitution is superior to any ordinary act of the legislature; the constitution, and not such ordinary act, must govern the case to which they both apply" at 178). With the enactment of the Constitution Act, 1982, judicial review is now expressly provided for under section 52(1), which states that any law that is inconsistent with a provision of the Constitution is "to the extent of the inconsistency, of no force or effect." However, this section is arguably superfluous since judicial review is a necessary function of a political order that places constitutional constraints on government power. Prior to 1982 , there was no question that the courts could strike down laws that offended the provisions of the BNA Act. During the Confederation Debates, there was some concern regarding how Parliament's power would be kept in check. George-Étienne Cartier explained that "the courts of justice will decide all questions in relation to which there may be differences between the two powers ... Should the general legislature pass a law beyond the limits of its functions, it will be null and void pleno jure" (Ajzenstat et al, Canada's Founding Debates, supra note 18 at 311).

See e.g. Jack M Balkin, Living Originalism (Cambridge, Mass: Belknap Press, 2011). See also Oliphant \& Sirota, "Rejected Originalism," supra note 101; Sirota \& Oliphant, "Originalist Reasoning," supra note 101 .

116 While the presumption of constitutionality no longer carries any weight where the Charter is concerned, such a presumption has been applied in the context of the Constitution Act, 1867. See Nova Scotia Board of Censors v McNeil, [1978] 2 SCR 662 at 687-88, 700. See also Asher Honickman, "The Paradoxical Presumption of Constitutionality" (2017) 46:4 Adv Q 421; Joseph Eliot Magnet, "The Presumption of Constitutionality" (1980) 18:1 Osgoode Hall LJ 87 at 116-21.

117 See Justice Stratas' dissenting opinion in Felipa v Canada (Citizenship and Immigration), 2011 FCA 272, [2012] 1 FCR 3 at paras 158-59 [citations omitted]:

Longstanding and consistent governmental actions, practices and understandings are to be given no overall weight in Charter adjudication - the Supreme Court has told us that there is no room for any sort of presumption of constitutionality under the Charter.... But presumptions of constitutionality - very much rebuttable in a particular case - have been applied in some contexts under the Constitution Act, 1867.... In our constitutional framework, the courts are responsible for making the final decisions on constitutional interpretation. They are duty-bound to strike down legislative and executive actions and practices that are wrong, even where they are longstanding and consistently followed. But we must recognize that these other branches of government do try, as they must, to keep their actions and practices within the limits of the powers given to them under the Constitution. This involves making judgments, implicitly or explicitly, regarding the limits in the Constitution. Other branches of government are interpreters of the Constitution. 
law. Where the judicial doctrine strays from the text but is long settled with deep roots, upholding that doctrine will often be preferable to getting it right.

On the other hand, if left unchecked, the presumption of constitutionality and stare decisis can produce a sort of "creeping encroachment," whereby questionable laws are upheld in the first instance and establish a precedent for even more controversial laws to be upheld in the future. This is precisely what Lord Sankey warned against with his sixty colours analogy. The courts must be ever vigilant in guarding against this creeping encroachment by continually returning to the text as new cases arise. Where the doctrine bears little resemblance to the text, is unworkable, or has not been applied with consistency, the judiciary should not be wary of steering the ship, gradually if necessary, back to the text.

The precise balance that ought to be struck between textual correctness and doctrinal consistency (to the extent there is a conflict) is beyond the scope of this article. ${ }^{118}$ What is clear is that, in the realm of the division of powers at least, the balance tilts firmly in the direction of the text. The concept of flexible federalism is more than simply extra-textual; it is contra-textual. It does not sit uncomfortably or even awkwardly with the text; it sits entirely apart. It affirms an idea that is fundamentally at odds with the exclusivity principle, whether the meaning of "exclusive" is fixed in 1867 or 2017.

Moreover, despite the consistent rhetoric in recent years in favour of "cooperative" or "flexible" federalism, the doctrine is anything but settled. While the Supreme Court has definitively moved in the direction of greater flexibility, ${ }^{119}$ old notions of exclusivity still permeate. The Supreme Court has relaxed the pith and substance doctrine, but it has also continued to enforce exclusive spheres. ${ }^{120}$ The Supreme Court has tended to be dismissive of Lord Atkin's watertight compartments metaphor, ${ }^{121}$ but has only overruled a few Privy Council decisions ${ }^{122}$ (and indeed, the Weekly Rest Reference, ${ }^{123}$ which first referred to the jurisdictional spheres as "watertight compartments," remains good law). The powers of the federal government, and particularly the criminal law power, ${ }^{124}$ have been expanded into areas once thought to be under exclusive provincial jurisdiction, ${ }^{125}$ but the Supreme Court has also maintained a narrow construction of the potentially broad federal power over trade and commerce, most notably in the 2011 Securities Act Reference. ${ }^{126}$ The doctrine of

118 This was the dilemma that Judge LeBlanc faced in $R v$ Comeau, 2016 NBPC 3, 448 NBR (2d) 1 [Comeau]. After discerning the original meaning of section 121 and determining that the Supreme Court's decision in Gold Seal Ltd v Alberta (AG) (1921), 62 SCR 424 [Gold Seal] was wrongly decided, Judge LeBlanc was left to determine whether the precedent in Gold Seal should be overturned whether, in other words, getting it right was more important than maintaining a consistent doctrine. Judge LeBlanc ultimately chose correctness. See Comeau, ibid at paras 115-25, 150-65.

Johanne Poirier, "Taking Aim at Cooperative Federalism: The Long-Gun Registry Decision by the Supreme Court of Canada" (15 April 2015), I-CONnect (blog), online: <www.iconnectblog.com/ 2015/04/taking-aim-at-cooperative-federalism-the-long-gun-registry-decision-by-the-supreme-court-ofcanada>.

See e.g. $R v$ Morgentaler, [1993] 3 SCR 463 [Morgentaler]; Isen v Simms, 2006 SCC 41, [2006] 2 SCR 349; Securities Act Reference, supra note 4.

See e.g. Quebec (AG), supra note 106 at para 17; Rogers Communications Inc v Châteauguay (City), 2016 SCC 23, [2016] 1 SCR 467 at para 37 [Rogers Communications]. Peter W Hogg \& Wade K Wright, "Canadian Federalism, the Privy Council and the Supreme Court: Reflections on the Debate About Canadian Federalism" (2005) 38:2 UBC L Rev 329 at 349.

Supra note 8.

Hogg \& Wright, supra note 122 at $348-49$.

Jean Leclair, "The Supreme Court of Canada's Understanding of Federalism: Efficiency at the Expense of Diversity" (2003) 28:2 Queen's LJ 411 at 423. 
interjurisdictional immunity has been improperly carved out as a narrow exception to the pith and substance doctrine, as opposed to a proper application of that doctrine; however, the Supreme Court still saw fit to apply it rigorously in the COPA decision of $2010 .{ }^{127}$

We thus have less a system of cooperative federalism than of conflicting federalisms a modern flexible approach that has somehow been grafted onto a traditional exclusivist framework. This has had the tendency to produce uncertainty for lawyers and litigants, who are left in the dark not only as to the probable result of each case, but even as to the interpretive methodology that will be used to arrive at the result. ${ }^{128}$ Crucially, it also means that the doctrine remains in a state of flux, and that a decision to "get back to the words of the Act" would not be impractical or doctrinally problematic.

There are five areas in particular where, in my respectful view, an exclusivist approach in keeping with the requirements of the constitutional text would promote coherent and stable doctrine, and thereby ensure that Canada's constitutional order remains rooted in the values of "legal certainty and predictability."129 They include: (1) the criminal law power; (2) the POGG power; (3) the provincial power over property and civil rights; (4) the doctrine of interjurisdictional immunity; and (5) the ancillary powers doctrine. Each of these areas warrants a separate discussion.

\section{A. Criminal LaW}

The Privy Council and the Supreme Court established and fine-tuned a very workable test for the criminal law power, recognizing that the essential and unchanging meaning of criminal law is "a body of prohibitions"130 that serve a traditional criminal law purpose, such as public peace, order, security, health, or morality. To that end, a valid criminal law must (1) prohibit conduct with penal consequences, and (2) be enacted for a valid criminal law purpose. ${ }^{131}$ These constraints, while very basic, still allow for a generous criminal law power. What they demand is that the power be confined to the suppression of societal evils.

In recent years, however, the Supreme Court has affirmed complex regulatory schemes that lack the prohibition versus penalty dichotomy, ${ }^{132}$ and also validated a law that was merely ancillary to a criminal law purpose. ${ }^{133}$ Whether or not these precedents should be overruled is, at present, an academic issue that awaits future consideration. In any event, they need not be relied upon in future decisions. The Supreme Court should reaffirm the

Supra note 2 .

A good illustration of this is OPSEU, supra note 4 at 17 , in which Justice Dickson, in his concurring opinion, referred to interjurisdictional immunity as "not a particularly compelling doctrine" and contrary to the pith and substance approach, followed one year later by Bell Canada (1988), supra note 67, in which the Supreme Court wholly embraced the doctrine of interjurisdictional immunity. Secession Reference, supra note 107 at para 53.

Reference Re Validity of Section 5(a) Dairy Industry Act, [1949] SCR 1 at 49.

Ibid at 49-50.

R v Hydro-Québec, [1997] 3 SCR 213; Reference re Firearms Act (Can), 2000 SCC 31, [2000] 1 SCR 783.

RJR-MacDonald Inc v Canada (Attorney General), [1995] 3 SCR 199. 
traditional criminal law test, lest the criminal law power become a vehicle for encroachment upon legitimate provincial jurisdiction, not to mention individual rights. ${ }^{134}$

\section{B. Peace, Order, AND GoOd Government}

The Supreme Court has, for the most part, ${ }^{135}$ constrained this potentially broad power and should continue to do so in the same principled fashion. Aside from genuine national emergencies, there are very few instances where a matter (1) will be truly a matter of national importance such that it is not captured by any of the heads of power in section 92 (especially property and civil rights), and (2) will not be captured by one of the other heads of power in section 91. A narrow reading of the POGG power follows more than a century of precedent and is in keeping with the exclusivity principle and the rules of statutory interpretation POGG being the most "general" power and thus limited by the more specific enumerations in section 92 .

\section{Property ANd Civil Rights}

There is every indication from the text and the history of the Constitution Act, 1867 that the power over property and civil rights is meant to confer very broad authority. ${ }^{136}$ However, even this expansive power, which covers virtually all aspects of private law, must have limits. In light of the rules of statutory interpretation and the non obstante clause, property and civil rights must be construed to exclude the more specific grants of power enumerated in section 91. Care should also be taken to ensure it does not consume the already limited federal power over trade and commerce. ${ }^{137}$

Beyond that, the power should not be used as a cloak for what properly belongs under the criminal law power. While the provinces are perfectly entitled to impose punishments for violations of laws enacted under the property and civil rights power pursuant to section 92(15), the purpose underlying these laws should be the regulation of property or civil rights, not the suppression of societal evils. Where the law prohibits conduct for a

The relationship between federalism and individual rights is beyond the scope of this article and awaits further consideration. For the time being, it suffices to say that there is much truth in Justice Cannon's observation in Reference Re Weekly Rest in Industrial Undertakings Act, [1936] SCR 461, that a federal form of government, though more cumbersome and expensive, gives "superior liberty" to the people (ibid at 521).

135 Reference Re Anti-Inflation Act, [1976] 2 SCR 373 is an unfortunate example of an overbroad application of the POGG power, in which inflation was deemed to be a national emergency.

136 Browne, Judicial Committee, supra note 29 at 96-98, 162-64.

137 In Manitoba (AG) v Manitoba Egg and Poultry Association, [1971] SCR 689 at 703, the Supreme Court found that the provincial scheme was ultra vires since

the Plan now in issue not only affects inter-provincial trade in eggs, but ... aims at the regulation of such trade. It is an essential part of this scheme, the purpose of which is to obtain for Manitoba producers the most advantageous marketing conditions for eggs, specifically to control and regulate the sale in Manitoba of imported eggs. It is designed to restrict or limit the free flow of trade between provinces as such. Because of that, it constitutes an invasion of the exclusive legislative authority of the Parliament of Canada over the matter of the regulation of trade and commerce.

Following this approach, I would propose that the courts examine whether the law, on its face, is an attempt to regulate interprovincial trade or whether the effect on interprovincial trade is merely incidental. See also Asher Honickman, "A Marriage Made in Britain: Section 121 and the Division of Powers" (21 October 2016), Advocates for the Rule of Law (blog), online: <www.ruleoflaw.ca/amarriage-made-in-britain-section-121-and-the-division-of-powers>. 
traditional criminal purpose, ${ }^{138}$ or does not relate, even on a generous reading, to a civil right in the province, ${ }^{139}$ that law cannot be supported under section 92 of the Act. In the current landscape, this is particularly relevant in the context of provincial hate speech laws, which arguably have the tendency of venturing into the domain of criminal law. ${ }^{140}$

\section{INTERJURISDICTIONAL IMMUNITY}

As discussed in Part III, the "core impairment" test developed by the Supreme Court in Canadian Western Bank is incompatible with the exclusivity principle, not to mention settled employment and labour law and company law. The Supreme Court should re-embrace the test articulated in Bell Canada (1988) and look to whether the law "affects" (not impairs) a "vital or essential" aspect of the work or undertaking. ${ }^{141}$ If so, then it is in relation to a "matter coming within" the federal work or undertaking and thus ultra vires. The Bell Canada (1988) test has historical roots, can be applied with greater ease, and most importantly, best reflects the text of the Constitution.

The doctrine of interjurisdictional immunity should not be treated as the "undertow" to the "dominant tide" of pith and substance, but rather as derivative of the pith and substance doctrine, applying in circumstances where a provincial law passed broadly under the property and civil rights power would, in its widest application, apply to federal works and undertakings. Justice Beetz, who authored Bell Canada (1988) (and who, incidentally, was a well-known proponent of provincial autonomy), correctly noted that the doctrine "does not confer on Parliament any power that it does not already have."142 As he explained, "[i]f this power is exclusive, it is because the Constitution, which could have been different but is not, expressly specifies this to be the case." 143

\section{E. AnCillary Powers}

The "rational, functional connection" test is contrary to the exclusivity principle. It has opened the door to unwarranted intrusions upon each order's jurisdiction and has left the provinces particularly vulnerable. What is more, the General Motors formula is both theoretically and practically problematic.

See e.g. Morgentaler, supra note 120 .

See e.g. Switzman v Elbling, [1957] SCR 285 [Switzman], and in particular, Justice Rand's concurring opinion at 300-307.

See André Schutten \& Richard Haigh, "Whatcott and Hate Speech: Re-thinking Freedom of Expression in the Charter Age" (2015) 34:1 NJCL 1 at 15-30. See also Switzman, ibid.

Bell Canada (1988), supra note 67 at 858-59. In Canadian Western Bank, supra note 4, the Supreme Court indicated that it favoured the approach supposedly used prior to Bell Canada (1988), in which the provincial law was only struck down where it impaired the core of a federal power. While John Deere Plow, supra note 72 did state that the provincial law cannot be permitted to "destroy" the federal undertaking (ibid at 341), which is naturally much stronger language than "affect a vital or essential" aspect (and is thus more akin to a "core impairment" approach), this language has to be read in its proper context. Firstly, the decision did not say that only a law that destroys the federal undertaking will be ultra vires. In Great West Saddlery, supra note 72, the Privy Council clarified that provincial legislation cannot "interfere" with the powers of the federal corporation and thus "affect its status," which clearly resembles the Bell Canada (1988) approach (ibid at 114-16). Secondly the federal power at issue in the Company Law cases was not the power to regulate a particular undertaking; it was a residual power to incorporate federal companies. To affect an integral part of Parliament's power to incorporate a company will necessarily impair that company since the power deals with the company's very existence, as opposed to its activities.

Bell Canada (1988), ibid at 840.

Ibid. 
The Supreme Court should return to the uniform approach that prevailed for the majority of Canadian history - namely, that the impugned provision must be necessarily incidental to the otherwise valid scheme. While the necessarily incidental doctrine is not based on an explicit textual provision, it is arguably implied by the constitutional structure, and provides a proper balance between the exclusivity principle and the general right of both orders of government to enact purposeful legislation.

\section{CONCLuSiON}

The Canadian Constitution is one of the oldest and most enduring in the world, and has provided the legal foundation for a free, stable, and prosperous society. One of the central features of its "original structure"144 is a model of federalism that divides and balances legislative power through mutually exclusive and limited spheres of jurisdiction. Under the Constitution, that exclusivity principle is "absolute." ${ }^{145}$ Canadian courts have, to some extent, strayed from the clear meaning of the Constitution by embracing a "flexible federalism" built upon overlapping jurisdiction. Historian Janet Ajzenstat's contention that the original division of powers "has all but disappeared"146 is perhaps overstated, but it is certainly the case that the division of powers is in grave danger of becoming a multiplication of powers. It is therefore incumbent upon the Supreme Court to halt and even reverse this trend wherever practicable. To paraphrase Justice Beetz in Bell Canada (1988), the Constitution could have been different, but it is not. ${ }^{147}$

The constitutional text does allow for a limited degree of overlap, provided the overlap is constrained by the exclusivity principle. This point is worth emphasizing, as the Supreme Court has, on more than one occasion, contrasted the "watertight compartments" approach with the doctrines of double aspect, ancillary powers, and even pith and substance. ${ }^{148}$ In fact, the concept of watertight compartments is perfectly consistent with these doctrines, and developed concurrently alongside them. The watertight compartments metaphor was never taken too literally and for good reason: some degree of overlap was inevitable under the constitutional framework. ${ }^{149}$ What distinguishes the textual approach embodied by the watertight compartments analogy, on the one hand, and flexible federalism, on the other, is not that the former prohibits overlap while the latter permits it, but rather that overlap is constrained under the former and facilitated under the latter.

One final point is in order. The Supreme Court often describes its flexible approach to the division of powers as "cooperative federalism," which is meant to evoke a less political posture that facilitates inter-governmental cooperation. The unspoken — and unproven ${ }^{150}$ assumption is that greater flexibility yields greater cooperation between the orders. But it is

Weekly Rest Reference, supra note 8 at 354.

Bell Canada (1988), supra note 67 at 840.

Janet Ajzenstat, The Canadian Founding: John Locke and Parliament (Montreal: McGill-Queen's University Press, 2007) at 99.

Bell Canada (1988), supra note 67 at 840.

OPSEU, supra note 4 at 18; Ontario Hydro, supra note 82 at 406.

AHF Lefroy took an exclusivist view of the division of powers, but acknowledged that the double aspect principle was perfectly consistent with that exclusivity. See Lefroy, supra note 10 at 394-415; Risk, supra note 10 at 50.

Wade K Wright, "Facilitating Intergovernmental Dialogue: Judicial Review of the Division of Powers in the Supreme Court of Canada" (2010) 51 SCLR 625 at 638-39. 
at least arguable that unfettered discretion serves as a disincentive for cooperation ${ }^{151}$ and is much more likely to produce federal domination by way of the paramountcy doctrine. ${ }^{152}$ Indeed, while "cooperative federalism" is contrasted today with Lord Atkin's watertight compartments approach, ${ }^{153}$ the concept of intergovernmental cooperation was initially advocated by the strict exclusivist Viscount Haldane ${ }^{154}$ and subsequently by Lord Atkin himself. Immediately prior to offering the watertight compartments analogy in the Weekly Rest Reference, Lord Atkin noted that certain legislative objectives could only be accomplished through "co-operation between the Dominion and the Provinces." 155 This echoed similar sentiments from his companion decision, British Columbia (A.G.) v. Canada (A.G.): "Unless and until a change is made in the respective legislative functions of Dominion and Province it may well be that satisfactory results for both can only be obtained by co-operation." 156

Thus, for these classical federalists, cooperation between the orders was achieved, not through the expansion of legislative jurisdiction, but from the orders' mutual recognition of the inherent limitations upon their respective powers. From this perspective, a return to watertight compartments need not be viewed as inconsistent with cooperative federalism. It may, in fact, prove to be a key ingredient to a more harmonious federation.

Marc-Antoine Adam, "The Spending Power, Co-operative Federalism and Section 94" (2008) 34:1 Queen's LJ 175 at 204:

$[W]$ ith hindsight, one may today question whether the notion of an unlimited federal spending power has indeed promoted co-operation between the federal government and the provinces. Tom Kent suggests that Ottawa should now simply bypass the provinces altogether and use its spending power to exert its influence over the provincial domain through direct transfers to individuals. This is perhaps the best evidence that co-operative federalism and the unlimited spending power thesis do not necessarily go hand in hand. In my opinion, if anything, this thesis has hindered the search for new and innovative ways to enhance genuine co-operative federalism, notably with respect to delegation. Interpretation of the Division of Powers" (2011) 54 SCLR 565 ("the combined effect of the federal paramountcy rule and the growth of areas of de facto concurrency poses a serious threat to the federal principle and its corollary, the principle of equal autonomy" at 595). Rogers Communications, supra note 121 at para 85.

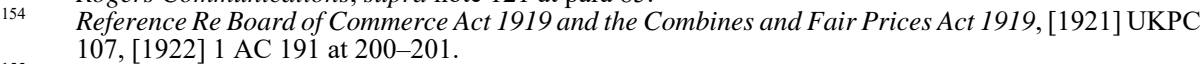


[this page is intentionally blank] 